UDK 39Križe, M.

398.5:821.163.42

https://doi.org/10.31337/oz.76.2.7

Pregledni rad

Primljeno: 23.6.2020.

Prihvaćeno: 9.3.2021.

\title{
Antropološko-folkloristički i vjerski aspekti usmenoknjiževnih zapisa Marice Križe
}

\author{
Tanja Baran*
}

\begin{abstract}
Sažetak
Kontekstualizacijom i analizom usmenoknjiževnih zapisa Marice Križe u križevačkom selu Dubovcu dobiva se uvid u obilje antropološko-folklorističkih $i$ vjerskih sadržaja koji su u 19. stoljeću bili izuzetno bogati $i$ snažni u identitetu hrvatskoga čovjeka. Ovim se radom želi istražiti žanrovski raznolik sadržaj dvaju rukopisa Marice Križe s kraja 19. i početka 20. stoljeća, kako bi se prikazala praktična, življena vjera, i u običajima i u sakramentalnom životu seljaka u potkalničkom Prigorju. Marica Križe jedina je zapisivačica usmene književnosti u križevačkom kraju i jedna od desetak žena u Hrvatskoj koje su bilježile narodni život i običaje prema knjizi Osnova za sabiranje i proučavanje građe o narodnom životu Antuna Radića pri Akademijinu Odboru na narodni život i običaje. Iako ona Radićeve naputke o zapisivanju gradiva nije usvojila cjelovito kao normu, nego više kao predložak, prema njima je zapisala tradicijske i usmenoknjiževne stvarnosti te time zabilježila življenu kulturu $i$ vjerske sadržaje na jednom lokalitetu.
\end{abstract}

Ključne riječi: Marica Križe; Antun Radić; usmena književnost; žanrovi; antropološki i vjerski sadržaji; folklorističko gradivo; žena zapisivačica; Odsjek za etnologiju $H A Z U$

\section{Uvod}

U 19. stoljeću diljem Hrvatske događala se je ekspanzija prikupljanja gradiva o narodnom životu, običajima i usmenoj književnosti. Ključne je poticaje u prvim desetljećima dao zagrebački biskup Maksimilijan Vrhovac. Uslijedilo je prikupljanje prema naputcima Ivana Kukuljevića Sakcinskoga, a u drugom dijelu 19. stoljeća u okrilju dviju središnjih kulturnih i znanstvenih institucija, najprije Matice hrvatske pa potom Akademijina Odbora za narodni život i običaje. Bio je to organiziran etnološki i fokloristički rad. Prikupljalo se je u svim hrvatskim krajevima. Zapise su prema potpunim obrascima ili fragmentarno u narodu stvarali

* Doc. dr. sc. Tanja Baran, Hrvatska radiotelevizija. Adresa: Prisavlje 3, Zagreb, Hrvatska. ORCID iD: https://orcid.org/0000-0002-2811-0346. E-adresa: tanja.baran@hrt.hr 
uglavnom obrazovani pojedinci, kulturna elita onoga vremena. Najviše su zapisivali učitelji na prostoru na kojem su živjeli i djelovali. Zapisivale su i žene. Istina, u vrlo malom broju u odnosu na muškarce. Ali ih je bilo. Svoje su zapise slali ili u Maticu hrvatsku, ako su se odazvali na Matičin poziv iz 1877., ili u Akademiju, ako su gradivo prikupljali prema Osnovi za sabiranje i proučavanje građe o narodnom životu iz 1897., koju je osmislio Antun Radić pri Odboru za narodni život i običaje (Radić, 1897). Posebno je Radić s tim svojim uputama za zapisivački rad na terenu udario temelje etnološke struke, a u prvom našem foklorističkom časopisu Akademijinu Zborniku za narodni život i običaje prikupljeno gradivo moglo je biti objavljeno, što je bila izvrsna mogućnost prezentiranja i analiziranja prikupljenoga, kao i motivacija za daljnja etnološko-folkloristička i usmenoknjiževna istraživanja. Poznate zapisivačice, mahom učiteljice, zapisivale su gradivo prema Radićevoj Osnovi. Pučka etnografkinja Katarina Jančir jedina je autorica čije je istraživanje o Trebarjevu objavljeno u Zborniku. Dubrovačke učiteljice Nike Balarin-Monopoli i Pavlina Bogdan-Bijelić dvije su Akademijine suradnice koje su radile samostalno, bez etnografskoga predloška, a u svojim su rukopisima pokazale sklonost prema svadbenim običajima, tradicijskim vjerovanjima, usmenoknjiževnim zapisima. Tri etnografkinje iz sjeverozapadne Hrvatske, Ana Wálka Stipetić, Marica Križe i Olga Jerman, iako su bilježile prema Radićevoj Osnovi, pisale su nedosljedno i fragmentarno. U njihovu su zapisivačkom fokusu ponajprije obitelj i obiteljski odnosi, zatim životni i svakidašnji običaji te folklorno stvaralaštvo. Učiteljica Milena Sajvert Pokupska jedina je zapisivačica koja je dosljedno slijedila strukturu Radićeve Osnove. Ona je ispisala djelo o Hrnetiću kroz dominantnu književno-folklorističku prizmu (Batina, 2015).

Marica Križe svoje je istraživanje ostvarila u križevačkom selu Dubovcu, koje je i središte župe s kojom je zapisivačica bila povezana. Autorica je jednoga od petnaestak usmenoknjiževnih rukopisa koji su nastali u križevačkom kraju tijekom 19. stoljeća.

\section{Identitet Marice Križe}

Jedina poznata žena zapisivačica usmene književnosti u križevačkom kraju u 19. stoljeću Marica Križe jedina je od svih zapisivača u križevačkom kraju popisivala folklorističko gradivo prema Osnovi za sabiranje i proučavanje grade o narodnom životu Antuna Radića. ${ }^{1}$

1 Antun Radić (Trebarjevo Desno, 11. lipnja 1868. - Zagreb, 10. veljače 1919.), hrvatski etnolog koji je od 1897. do 1901. uređivao Zbornik za narodni život i običaje Južnih Slavena, što je bio prvi hrvatski etnološko-folkloristički časopis u Akademijinu izdanju. Zalagao se je za politička prava seljaka. Pokrenuo je 1899. novine Dom: List hrvatskomu seljaku za razgovor i nauk, prvi hrvatski časopis namijenjen seljaštvu. Etnologijom se je bavio kratko od 1896. do 1902., ali su ga njegove teorijsko-metodološke zamisli i koncepcije u djelu Osnova za sabiranje i proučavanje građe o narodnom životu (1897.) učinile utemeljiteljem hrvatske etnologije kao samostalne znanosti. Taj je priručnik zamišljen kao iscrpna i opširna uputa za etnografski rad na terenu te kao sredstvo za istraživanje seljačkoga života. U uvodnom dijelu Radić je istaknuo da treba utemeljiti novu 
Svoje djelovanje usmjerila je na križevačko selo Dubovec kraj Velikoga Ravna. Opisala je zemljopisni položaj Dubovca, prirodne specifičnosti, ljude, čime se ljudi bave, kvalitetu stanovanja, narodnu medicinu, prehranu, nošnju, određene običaje, porod, sprovod te je dala detaljan opis ženidbe. Daljnji dio rukopisa sadrži lirske pjesme, pripovijetke, zagonetke i vjerovanja. Taj rukopis čuva se u arhivu Odsjeka za etnologiju HAZU u Zagrebu u kolekciji Stare zbirke. ${ }^{2}$

Nije poznato tko je bila Marica Križe. Zapisivačica je znala pisati, pa je pretpostavka da je bila učiteljica ili supruga nekoga obrazovanoga čovjeka koji je u Dubovcu živio i djelovao. Uvidom u korespondenciju vidljivo je da je Marica Križe poslala četiri pisama uredniku Zbornika za narodni život i običaje iz Dubovca u vremenskom razdoblju od 8. veljače 1899. do 12. svibnja 1907., pa je za pretpostaviti da je u tom selu i živjela. Samo je zadnje pismo poslala iz Visokoga kraj Gornje Rijeke 1. ožujka 1913. godine. Zašto iz Visokoga, može se samo nagađati. Tih pet pisama u vremenskom razdoblju od 8 . veljače 1899. do 1. ožujka 1913. čuvaju se u arhivu Odsjeka za etnologiju HAZU u Zagrebu. ${ }^{3}$

Uvidom u spomenicu područne škole Dubovec (od 1872. do 1966.) vidljivo je da Marica Križe nije bila zaposlenica škole. ${ }^{4}$ Njezina imena nema ni u matici krštenih, vjenčanih i umrlih župe Dubovec. ${ }^{5}$ Urednik Zbornika za narodni život $i$ običaje Dragutin Boranić uz njezino je ime na primljenom folklorističkom gradivu napisao: »čini se seljanka? «. ${ }^{6}$ Navodno seljačko podrijetlo Marice Križe najvjerojatnije je samo Boranićeva pretpostavka. Velika je vjerojatnost da ipak nije bila seljanka jer je u trećem pismu koje je poslala uredništvu Zbornika 23. ožujka 1904., pišući o teškoćama pri prikupljanju folklorističkoga gradiva, napisala da ju je jedan muškarac upitao: »Čuju gospa zdopuščejnem, a kaj oni te trebaju. Te bu pak za kakvu štikru. Kaj nas oču i oni Magjarem predati.« Zapisala je i »da mu je svaki neprijatelj, kaj crni kaput nosi«. Da je bila domaća seljanka, seljak bi je poznavao, ne bi ju oslovljavao kao gospu te ne bi bio tako nepovjerljiv. Seljaci, očito, nisu imali novca za crne kapute. Iz toga se dade zaključiti da je Marica Križe bila gošća u Dubovcu te da nije bila seljanka, ali je tada upitno kako to da je pisma slala iz Dubovca, uz isticanje poštanskoga središta na kraju pisma »Dubovac kod Križevca pošta Raven«.

znanost, narodoznanstvo ili etnologiju, čiji bi predmet istraživanja bio narod i narodna kultura. Radić je postavio tezu o dualnoj socio-kulturnoj strukturi hrvatskoga naroda, koja se sastoji od naroda (seljaka) i "gospode" (neseljaka), te da svaka od tih dviju sastavnica ima svoju kulturu. Samo narodnu, seljačku kulturu on je smatrao izvornom hrvatskom, objašnjavajući da su se u "gospodsku" kulturu uvukli tuđinski utjecaji. Njegov je izričiti zahtjev bio da gradivo o narodnom životu zapisuju oni koji po njegovu uvjerenju jedini mogu spoznati "dušu narodnu”, oni koji u toj kulturi žive i sudjeluju, dakle sami seljaci, i to doslovnim zapisom, odnosno u svojem izvornom govoru, ili eventualno intelektualci seljačkoga podrijetla (primjerice seoski učitelji i svećenici) (Ravlić, 2007, s. v. Radić, Antun).

2 HR-HAZU. Odsjek za etnologiju. Sign. K.SZ.85. Dubovec kraj Križevaca (po Osnovi).

3 HR-HAZU. Odsjek za etnologiju. Sign. K.SZ.390/1,2,3,4 i 5. Pisma Marice Križe uredništvu časopisa Zbornik za narodni život i običaje od 8. veljače 1899. do 1. ožujka 1913. godine.

4 Spomenica opće pučke škole u Dubovcu od 1872. do 1966.

5 Župa Dubovec. Matica krštenih, vjenčanih i umrlih od 1800. do 1991. godine.

6 HR-HAZU. Odsjek za etnologiju. Sign. K.SZ.125. Ostavština Dragutina Boranića. 
Prema usmenoj predaji koju je izgovorila časna sestra Kćeri Božje ljubavi Arkadija Barica Rusan, Marica Križe bila je osoba koja je neko vrijeme iz Dubovčanima nepoznatih razloga živjela na župnom dvoru kod dubovečkoga župnika Gabrijela Golubića. S. Arkadija ispripovijedala je da je njezin djed pričao da je kod župnika stanovala jedna Marica koju su seljani nazivali gospođom. ${ }^{7}$ Inače je iznimno načitan i obrazovan dubovečki župnik Gabrijel Golubić, rođen u križevačkom selu Podgajcu 1843. godine, u Dubovcu službovao od 1875. do 1910., kada je izgorio u župnom dvoru (Vrabec, 2011, 112). Kako je Marica Križe već spomenuta prva četiri pisma u razdoblju od 1899. do 1907. godine Odboru za narodni život i običaje u Zagrebu poslala iz Dubovca, a posljednje je pismo 1913. godine poslala iz Visokoga, moguće je da je poslije požara, u kojem je 1910. izgorio župnik Golubić, svoj novi dom Marica Križe pronašla u Visokom.

Prema tome, nakon uvida u dostupne pisane podatke, možemo zaključiti da Marica Križe nije bila rođena Dubovčanka, nego da je u tom kraju obavljala neku službu, pa je stanovala kod dubovečkoga župnika. Pisanih tragova o tom nema. Ostala je samo usmena predaja s. Arkadije Barice Rusan.

\section{Objavljeno gradivo, rukopisi i sadržaji zapisa Marice Križe}

Marica Križe folklorističko gradivo u Dubovcu zapisivala je prema Radićevoj Osnovi, ali je zapis samo djelomičan. Zapisivačica, naime, nije obuhvatila sav sadržaj koji je Radić zamislio da bi trebalo obraditi. Njezin zapis, prema Boranićevu opisu, prikazuje »partice I-IV. 5. VIII. X1 (priroda, životne potrepšt., ženidba, nešto iz vjerovańa)《. Boranić je još nadodao da »dijalekt neće biti najtočniji (glasovi!), partija o ženidbi vjerna, ostale kao da nijesu tako točne. Izostavljańem i preradbom bit će koja 2 ar..$^{8}$ Vjerojatno je od cjelokupnoga folklorističkoga gradiva iz Dubovca zapisivačice Marice Križe u Zborniku za narodni život i običaje zato i objavljen samo sadržaj ženidbe (Križe, 1903). Zbornik su urednički potpisali Tomo Maretić i Dragutin Boranić. Iz pisama koje je Marica Križe slala uredništvu Zbornika vidljivo je da nije bila zadovoljna time što je od cjelokupnoga gradiva objavljen samo dio o ženidbi. U posljednjem, petom pismu, koje je posla iz Visokoga 1. ožujka 1913. napisala je: »Uslobodjujem se Vas opet veleučeni Gospodine za razjašnjenje glede 'Zbornika' i moje gradje, najme, da li je došlo što u tisak moga. Vrlo bi željela jedan istisak imati ako je poslje koji izdavan najme Zborniku, u tom slučaju, ako je moja gradja uvrštena. Ljepo bih Vas molila ako još nije došlo u tisak možda bi bilo moguće da dodje čim prije jer bi rada viditi moju muku «. ${ }^{9}$

7 Do usmenoga kazivanja s. Arkadije Barice Rusan autorica ovoga rada došla je zahvaljujući mr. sc. Marici Vrabec.

8 HR-HAZU. Odsjek za etnologiju. Sign. K.SZ.125. Ostavština Dragutina Boranića.

9 HR-HAZU. Odsjek za etnologiju. Sign. K.SZ.390/5. Pismo Marice Križe uredništvu časopisa Zbornik za narodni život i običaje od 1. ožujka 1913. godine. 
Rukopis Marice Križe nije datiran, ali je prema evidenciji rukopisnoga gradiva za Zbornik za narodni život i običaje moguće zaključiti da je rukopisno gradivo zaprimljeno u dva navrata tijekom 1899. i 1904. godine. ${ }^{10}$ Prema prvima trima pismima koje je Marica Križe slala uredništvu Zbornika, moguće je potvrditi taj podatak.

Prvo je pismo slala 8. veljače 1899. godine. ${ }^{11} \mathrm{U}$ njemu piše da šalje gradivo za Zbornik, da ništa u rukopisu nije izmišljeno, da je sve opisala vjerno jer da se u Dubovcu u kajkavštinu miješa štokavština. Objasnila je da su pjesme najviše štokavske, ali da se te pjesme u Dubovcu tako pjevaju.

U drugom pismu od 14. listopada 1903. godine ${ }^{12}$ Marica Križe odgovorila je na upit uredništva bi li htjela u Dubovcu nastaviti zapisivati narodne običaje. Odgovorila im je da je ona običajno gradivo već bila poslala Radiću, tadašnjemu uredniku te da je konkretno opisala »mjesto, položaj, krstitke, ženitbu, karmine, i u obće ova selske običaje ovoga mjesta i mnogo pjesama koje se pjevaju ovdje «.13 Zapisivačica je još nadodala da joj je Radić javio da će nešto morati ispraviti jer da je manjkavo, ali kako joj rukopis nije vratio na ispravljanje, te je mislila da je ipak sve u redu. Na kraju je zaključila da ipak nije bilo sve u redu, jer je u Zborniku objavljena samo Ženidba.

U trećem je pismu od 23. ožujka 1904. godine ${ }^{14}$ Marica Križe javila da šalje nastavak gradiva za Zbornik. Objasnila je kako je zapisivanje težak posao jer je narod nepovjerljiv, da muškarci misle kako im je svatko neprijatelj te da sva tumačenja i obrazlaganja ne koriste. Nekima je, napisala je, čak dala Zbornik od ranijih godina u kojem su običaji iz Slavonije, da se osvjedoče o svrsi zapisivanja. Istaknula je da je tek tada dobila gradivo koje šalje. Posvjedočila je da narod obiluje pripovijetkama i zagonetkama. Zato je taj mlađi njezin dio rukopisa gotovo u cijelosti usmenoknjiževni, posvećen žanrovima pripovijetke i zagonetke. Na kraju toga pisma dopisala je: »Na skrajnom listu je dodatak pokopu kojega več imadete, ovo sam tekar sada saznala. «To znači da je s pripovijetkama i zagonetkama poslala obogaćen opis običaja sprovoda u odnosu na raniji rukopis koji je poslala 1899. godine.

Sadržaj rukopisa iz Dubovca najlakše je pratiti baš prema godinama slanja u Odbor za narodni život i običaje u Zagrebu. Prvi dio rukopisa iz 1899. odnosi se na obradu gradiva prema poglavljima I-IV, VIII i X Radićeve Osnove. Na str. 1-3 opisan je kraj, na str. 4-5 opisani su ljudi, na str. 5-6 govor je o liječenju bolesti. Opis kuće (hiže) je na str. 6-8, prehrana se obrađuje na str. 8-19, nošnja na

10 HR-HAZU. Odsjek za etnologiju. Sign. K.SZ.109. Evidencija rukopisne građe za Zbornik za narodni život i običaje.

11 HR-HAZU. Odsjek za etnologiju. Sign. K.SZ.390/1. Pismo Marice Križe uredništvu časopisa Zbornik za narodni život i običaje od 8. veljače 1899. godine.

12 HR-HAZU. Odsjek za etnologiju. Sign. K.SZ.390/2. Pismo Marice Križe uredništvu časopisa Zbornik za narodni život i običaje od 14. listopada 1903. godine.

13 HR-HAZU. Odsjek za etnologiju. Sign. K.SZ.390/2. Pismo Marice Križe uredništvu časopisa Zbornik za narodni život i običaje od 14. listopada 1903. godine.

14 HR-HAZU. Odsjek za etnologiju. Sign. K.SZ.390/3. Pismo Marice Križe uredništvu časopisa Zbornik za narodni život i običaje od 23. ožujka 1904. godine. 
str. 19-22. Slijedi zapis o porodu na str. 23-25 te o ženidbi u poglavlju o odabiru bračnoga druga i prigledima, uz zapis 36 svatovskih pjesama na str. 25-49.

Drugi dio rukopisa iz 1904. meko je uvezani svezak koji sadrži 22 pripovijetke na str. 50-85, zatim 83 zagonetke na str. 86-102 te opisi Kak se vuroki nameću (str. 103), Kak se pregovara koga kača ugrisne (str. 104) i Dodatak pokopu koji je već opisan (str. 105).

Rukopis se sastoji od neuvezenih araka i naknadno paginiranih listova. U njemu je osam strojopisom pretipkanih stranica originalnoga rukopisa (str. 86-105). Svi sadržaji rukopisa odgovaraju Evidenciji. ${ }^{15}$ Format rukopisa je 21 x $34 \mathrm{~cm}$.

U Institutu za etnologiju i folkloristiku u Zagrebu čuva se prijepis dijela te rukopisne zbirke, koji je načinjen 1965. godine. U njemu je cjelovito prepisan mlađi dio rukopisa iz 1904. godine: pripovijetke, zagonetke, dva vjerovanja i dodatak opisa pokopa. U opisu prijepisa navedeno je: »Ova rukopisna zbirka sadrži osim pripovijedaka još 36 narodnih pjesama, opisa kraja i ljudi, narodnu medicinu, opis kuće, nastambe, prehranu (razna jela), nošnju, porod, ženidbu i 80 narodnih zagonetaka. Prepisane su samo pripovijetke a ostala građa će se naknadno prepisati. Na prvom listu napisano je olovkom, vjerojatno prilikom preuzimanja rukopisa, 25. III. 1904. Rukopis nema paginaciju, niti naslov.«16

\section{Antropološko-folkloristička analiza križevačkoga sela Dubovca}

Uvodno u rukopisu u opisu kraja Marica Križe piše da Dubovec pripada općini Raven, da je okolica lijepa i zdrava, više bregovita nego ravna, da nema pravoga puta te da je zato, kada padne kiša, takvo blato da je domorodcima teško doći do središta općine u Ravnu. Zatim opisuje obližnji mlin, koji je vlasništvo križevačkoga vlastelina Josipa Kipaha. Ističe da svi Dubovčani melju brašno u tom mlinu, prema kojemu idu dva potoka: Kamešnica, koja teče pokraj sela Oslavca, i Črnec, koji teče kraj sela Kučari. Govori i o teškoćama stanovništva nakon proljetnoga izlijevanja potoka. Objašnjava da su uz sela Oslavec i Kučari uz Dubovec vezana obližnja sela: Tkalec Gornji, u kojem imanje ima križevački biskup Julije Drohobecki, Tkalec Donji, Doljanec, Pavlovec, Beketinec, Dubovec Donji i Dubovec Gornji, te da su u svim tim selima jednaki običaji i nošnja. Zatim opisuje dubovečku župnu crkvu, pogled s brijega na kojem je crkva, šume, vinograde, urod, divlje životinje, biljke. U nastavku analizira fizičku konstituciju stanovnika, natalitet i mortalitet u selu, fizičke mane na ljudima, recepte narodne medicine. Zatim opisuje kuće i dvorišta u kojima Dubovčani žive. Slijedi dosta opsežan prikaz dubovečke prehrane s receptima za svaku vrstu hrane te opis nošnje za djecu, djevojke, žene, muškarce i dečke. Marica Križe zatim je opisala porod u kući, popisala je imena koja Dubovčani daju svojoj novorođenčadi, te opisala

15 HR-HAZU. Odsjek za etnologiju. Sign. K.SZ.109. Evidencija rukopisne građe za Zbornik za narodni život i običaje.

16 HR-IEF. Dokumentacija Instituta za etnologiju i folkloristiku. Križe, Marica. Folklorna građa iz Dubovca, 1904. Rkp. 446. 
običaj pogača, prigleda nakon poroda. Posebno detaljno opisani su običaji oko ženidbe od trenutka mladićeve želje da se oženi do običaja tjedan dana nakon ženidbe. Posebna je vrijednost toga dijela u Zborniku za narodni život $i$ običaje 1903. godine objavljenoga rukopisa u tom što je, osim opisa običaja, zapisivačica popisala također izreke i dijaloge među akterima koji se izgovaraju u pojedinom dijelu običaja ženidbe te četiri napitnice. Zapisani su i stihovi pjesme koje pet djevojaka pjeva mladenki, ali i stihovi koji se pjevaju »starešini, putnom čestniku, deveru, deverovem detetu i vujnevci«.

\section{Usmenoknjiževni zapisi — poezija, proza, zagonetke, vjerovanja}

U rukopisu o Dubovcu, nakon antropološko-folklorističkih sadržaja, slijede pjesme. Prva je pjesma nenumerirana i zavedena pod naslovom Pesma. Slijede pjesme iznad kojih umjesto naslova piše Pjesma 2, Pjesma 3, i tako do broja 36. To znači da u rukopisu ima 36 lirskih pjesama. Riječ je o štokavskim i kajkavskim pjesmama, većinom ljubavnoga sadržaja, pisanih ponajviše osmercem, desetercem ili dvanaestercem. I ta rukopisna zbirka sadrži inačice dviju pjesama koje su i u većini ostalih usmenoknjiževnih zbirki pjesama iz križevačkoga kraja u 19. stoljeću. Riječ je o pjesmama Sva se sila na Francusku zbila (Pjesma 19) i Sokol leti preko Budim grada (Pjesma 26). Posebnih opisa uz pjesme nema, osim što uz 36. pjesmu piše Pjesma čista pastirska 36. Time završava stariji dio rukopisa Marice Križe iz 1899. godine.

Poveći dio mlađega, gotovo čisto usmenoknjiževnoga rukopisa o Dubovcu Marice Križe iz 1904. godine proznoga je karaktera. Riječ je ponajprije o 22 pripovijesti vrlo različitoga sadržaja, ali i nekih sličnih karakteristika. Sve su priče napisane na kajkavskom narječju, no nerijetko je to neobična, iskrivljena kajkavština. Ponajprije leksikom priče odudaraju od govora kojim izvorni govornici govore u Dubovcu. ${ }^{17} \mathrm{U}$ pričama su često zarezi stavljani na krivim mjestima, a i svi upravni govori u svim pričama nisu nikako obilježeni, pa se, ako se čitatelj ne udubi u tekstove uz punu koncentraciju, teže snalaziti po tekstu. Sadržajno priče obiluju raznim narodnim mudrostima, primjerice moralni a bedasti bolje prolaze od pametnih a nesnalažljivih. U više su priča glavni protagonisti trojica braće ili prijatelja, od kojih jedan, najčešće bedastiji, iz raznih razloga najčešće bolje prolazi. Češća je vodilja priča važnost vjere u Boga i dobar životni prolaz svih onih koji su od Boga tražili pomoć. U pričama susrećemo mitološka bića (uglavnom vile, vukodlaka, zmaja, vodenjaka), a redoviti su i fantastični, pa i naturalistički elementi. Od fantastičnih se motiva, primjerice, spominje moć zlatne jabuke ili košulja uz čiju je pomoć moguće postati jak. Nerijetko je i pretvaranje ljudi u

17 Mišljenje o iskrivljenom jeziku u pričama Marice Križe dao je urednik Zbornika za narodni živote i običaje Dragutin Boranić u svojoj Ostavštini (SZ 125). To mišljenje potvrđuje i autorica ovoga rada, koja je mnoge dane svojega djetinjstva provela u Dubovcu kraj Križevaca, gdje joj je odrasla majka i gdje su joj živjeli baka i djed, pa poznaje leksik i jezične konstrukcije izvornih govornika u selu Dubovcu. 
životinje ili oživljavanje mrtvih osoba. Od naturalističkih elemenata najizrazitiji su motivi rezanja ljudi na komadiće ili kuhanje ljudi.

Nakon proznih oblika, Marica Križe u rukopisu je iz Dubovca zabilježila još i 83 zagonetke, koje su također napisane na kajkavštini, te je nakon zagonetke u dodatku odmah ispisala rješenje.

Rukopis s podnaslovom Zaklinjanja Marica Križe završila je tekstovima: Kak se vuroki nameću, Kak se pregovara koga kača vgrizne te opisom dodatka pokopu pod naslovom Dodatak pokopu, kaj je već opisan, koji je Marica Križe prvotno već bila opisivala u rukopisu iz 1899. godine. I ta su tri opisa na kajkavštini te su kombinacija teksta koji se izgovara u unaslovljenim prigodama te opisima izvedbe.

\section{Vjerski aspekti usmenoknjiževnih zapisa Marice Križe}

I u antropološko-folklorističkim, kao i u usmenoknjiževnim, zapisima obiju rukopisnih zbirki Marice Križe naglašeno su istaknuti vjerski sadržaji. Iz gradiva se jasno razabire kako je velik utjecaj vjere i ukorijenjenoga katoličanstva u identitet stanovnika istraživanoga križevačkoga sela. Doznaje se o crkvenim objektima, ali i o duhovnom životu ljudi.

Uz župnu crkvu sv. Margarete, župni dvor i župna materijalna dobra, zapisivačica opisuje također položaj crkve, okoliš, pogled na druge župe, a upućuje i na obližnje imanje križevačkoga grkokatoličkoga biskupa Julija Drohobeckoga:

U Dubovcu gornjem je cirkva, farof, škola, i 5 mužkih hiž. Dubovec gornji je u žlebu. Cirkva je na Visokem bregu na lepem vidiku, na sve strane se lepe vidi; vidi se susedna fara Miholjec, Sv. Peter Orehovec i Kalnik. Pod bregem je farof starinski, odspodi je zidan, a prvi štuk je drveni, tak je star i slab, da se sve steple kad se hodi po hižah.

Od farofa ide se po štengah do cirkve kojih 82 ima. Iz svih sel mora narod iti po tih štengah u Cirkvu izvan sela Beketinca, koje selo je od severa za Cirkvem na bregu. Na druge strane žleba na jugu je tekajše breg i lepa mlada šuma, župnička i mužka lisičak zvana, ta je velika šuma od juga sve okoli do severa, u žlebu je lepo spole. [...]

U Dubovec pripaćaju još i ova sela brez Oslovca i Kučara, Tkalec gornji u tem selu ima imajne Presvetli gos: biškup Križevečki Julio Drahobecki.

Marici Križe seljani su povjerili i svoje teškoće s kojima su suočeni kada zbog nevremena ne mogu poći na misu. Posvjedočili su i svoje pouzdanje u Boga: »Kuliku put nemru ljudi k meši dojti koj su prek vede, prek im zna de hižnega praga dojti, onda same Boga prosime da šte neobeteža kajti nebi mogli niti Doktora niti svečenika debiti.«

Uz pouzdanje u Boga, posvjedočili su joj i poznavanje deset Božjih zapovijedi te poštivanje Boga kao apsolutnoga autoriteta:

Prve nisu veruvali da bi te debre bile, rekli su kaj bi Boga varali i proti Bogu silu delali, em vre bu pak Bog rod dal, tak su jednega leta gusenice došle, da jih je tulike bile sikud kak mravlah, kulike sme jih tamanili i lepice lovili pak jih je se više bile, onda su poklam same neham otišle, pak bu tak i zgoricami. 
Iz rukopisa Marice Križe doznaje se i o otvorenosti seljaka životu te o prihvaćanju života kao Božje volje za svakoga pojedinca: »Dubovčanke imaju dece dosti, one jih se ne boje, vele, kad jih Bog dal moram jih imati, je briga je, ali pak proti Bogu nemreme, morame terpeti kaj Bog zapoveda, ima po dvoje, troje i više nekoje po šest i sedam.«

Marica Križe opisala je raznolike običaje i bogatu tradicijsku kulturu sela Dubovca. Iz zapisa se doznaje o odijevanju najsvečanijega ruha kada se odlazi na misno slavlje:

Kad idu k meši, cure imaju rubače od končeca lepe bele i polebane i lepe gladke zvalane, onda imaju lepe reklece, od baršuna črnega i špice odspod prišite, nekoje imaju od blota, i lastina, koje su siromašnejše i od cajga, vzimi imaju pak od sukna i od štofa, a sve imaju špice odspod pri šite, onda ima kraljuš beli debeli i črleni, nekoja i drobnega vaščenega, odzadi na kraljušu imaju male mašlne od svakejakih vuzkih privezačev ne preveć te pe pleči visi, kakve je na pleči, takve ima na prsih na reklecu, te si ziglum pribode, kaj od kramarof kupe (broš).

Seljani su zapisivačici opisali i običaje oko krštenja, ali i da djeci daju imena iz biblijskih vremena i iz kršćanskoga nasljeđa:

Na krst nese navek dve žene, kuma i druga koja je pomaže nesit. Muškemu davaju ove imena: Franc, Jendraš, Imbrek, Jožek, Marke, Gjurek, Štef, Matek, Ivanec, Mikec, Miške, Jadan (Adam) i Karlek, Jakopec, Tomaš, Gobrek i Ludvič. Ženskim: Jaga, Jana, Jalže, Mara, Kata, Magda, Dora, Tereza, Jula, Jela, Jarša (Urša), Margeta, Eva.

Kad je dete pokrščene, onda kuma dane detetu pod glavicu dar, koja dva zeksera, koja tri, koja i pet zekserov, kak je več koja premoguča.

Najdetaljnije je Marica Križe opisala ženidbene običaje u križevačkom selu Dubovcu. Vjerojatno je zbog cjelovitosti zapisa samo Ženidba od svega zabilježenoga gradiva i objavljena u Zborniku za narodni život i običaje. Ti običaji obiluju zdravicama, prigodnim govorima, izrekama, blagoslovima, dobrim željama. Redovito se u njima zaziva Bog, traži se Božji blagoslov za mladence i sve dobro u njihovu zajedničkom životu.

Svati se furt sprehajaju van i nuter, nigdar nisu pri miru. Gda ide van i onda natrag kad dojde, svaki veli: "Hvalen budi Jezuš Kristuš! Ja sem čul takev glas, da je dragi Jezuš i Marija pri vas." Kulike goder put ide van i nuter, svaki put tak veli. Onda i napi $\neg$ jaju mladenki i starejšim i svim, kak je ova napitnica: "Bog pre-križi naše jele i pile i sve dobre dele. Bog prekriži i poživi sve skupa, nas i vas, ki ste došli gledet nas. Daj nam Gospodin Bog put pravice, da dojdeme svi pred božje lice, gde se svi verni vesele i oca Boga u lice glede. Daj nam Gospodin Bog onaj mir, v kojem je dragi Jezuš bil, i onaj. stan, v kojem je dragi Jezuš stal. U ime božje i u blagoslov božji, naša se mladenka odpravla na božji put, i Bog je ga dej! Naša mladenka prosi od svoga oca i matere božji blagoslov, i Bog je ga dej! Mi se odpravlamo z našu mladenku na božji put, Bog nam ga prekriži i preblagoslovi! Ake nam tko ste oče na ovom putu zatepsti, daj nam dragi Bog ono sve rastepsti!"

Slijede usmenoknjiževni zapisi zabilježeni izvan konteksta pojedinih običaja. Među zapisanim pjesmama više ih je u kojima se zaziva Bog. 


\section{Pjesma 3.}

Ja si gledam na pendjer

Z Bogom ostaj Belovar

Ja odlazim stebe sada

Dvanajstoga listopada $[\ldots]$

Pjesma 6.

Z Bogom ostaj mili stan

Gjde ja rodjen jest moj stan

Oj junači cveti zeleni

A snašice cvet rumeni [...]

I zagonetke su nerijetko protkane zazivanjem Boga, ufanjem u Boga.

Falen Bog baka, ti paseš sto gusaka.

Baka: nije ji sto, nek, da ji je još jen put tulike, i pol tulike, i frtal tulike, i ja žnimi, onda bi ji bile sto. Bile ji je 36 i još jenput 36 i pol tuleke je 18, i fertal tulike je $9 \mathrm{i}$ baka š nlmi čini se zajene 100.

Jeden veli svani Bože, drugi veli nesvaki Bože, trejti veli svani ili nesvani, kak mi je tak mi je — vrata, postela, greda.

O prepletanju kršćanskoga i poganskoga u hrvatskom narodu od davnina svjedoči dubovečki zapis posvećen urocima. U njemu se traži pomoć Boga i Majke Božje pri otklanjanju uroka.

Kak se vuroki nameču

U ime oca i sina i duha svetega.

Bože pomozi, i Marija majka Boža. (Iti jen vuglen vu vodu) Vi ste vureki. Niste vureki nek ste vuričići. Ake ste devojački ote (hodte pod partu. Ake ste junački ote pod škrilok. Ake ste ženski ote pod peču. (Pak iti vuglen vu vodu) Ake ste muški, ote pod kapu. Ili ste stranski ili ste domači, ili ste jutrejšni ili opoldešni, ili ste večerešni. Ja vas zgajnam iz ovega tela (mora se imenuvati komu vuroke nameče, Mato, Bara, Mara, ili kak bile več onem ime, ili maržetu mora se reči negve ime) zmojum rečjum, i z Božjum pomočjum i prečiste blažene device Marije (iti pak vuglen vu vodu) neznajuč ste došli, neznajuč se i rastepite. Oče naš, zdrava Marija (nesme se reći nigde Amen) U ime oca, i sina i duha svetega. Kak ste obeteža, da ima vručinu, ili da ga glava boli, te je prve da se veli, vrečen je, onda zovu ženu koja te zna vuroke nametati, ake ozdravi onda su hasneli vuroki, i bil je onda vrečen. Ake mam neozdravi onda idu po drugu babu, koja bole zna, kajti od sake nehasne. Nekaj plati kaj, nekaj, nikaj. Same joj daju piti i jesti.

Molba Bogu za pomoć uz vjeru da će Bog pomoći, te uz opis aktivnoga sudjelovanja Gospodinova, Majke Božje i sv. Augustina, upućivala se je i kada je nekoga ugrizla zmija:

Kak se pregovara koga kača vgrizne

Najprve se moli Oče naš. Ali se nesme reči amen.

Išel je putem Gospodin Bog, i majka Božja, zestal se je Gospodin Bog, i majka Božja svetim Augustinem. Pital je Gospodin Bog i majka Božja svetega Auguština. Kam ti sveti Auguštin ideš? Ja sveti Auguštin idem N.N. koga kača v grizla vračit. 
Išel ja putem sveti Auguštin, zestal se je z Gospodinom Bogom i z majkom Božjom. Pital je sveti Auguštin Gospodina Boga i majku Božju. Kam ti Gospodin Bog i majka Božja ideš? Ja Gospodin Bog i majka Božja, idem vračit N.N. koga je kača vgrizla.

Išel je putem Gospodin Bog, i majka Božja. Zestal se je Gospodin Bog i majka Božja svetim Augustinem. Pital je Gospodin Bog i majka Božja svetega Auguština. A kam ti sveti Auguštin ideš. Ja sveti Auguštin idem vračit N.N. kega je kača vgrizla.

Te se mora devet put opetuvat. Deveti put se veli.

Išel je putem Gospodin Bog, i majka Božja, zestal se je Gospodin Bog i majka Božja svetega Auguština. Pital je Gospodin Bog i majka Božja svetega Auguština. A kom ti sveti Auguštin ideš? Ja sveti Auguštin idem vračiti N.N. kega je kača vgrizla. Veli Gospodin Bog i majka Božja, Nejdi, vrni se, on je već ozdravil.

Sad se moli Oče naš, zdrava Marija, i veru Božju, same se nesme nigde reči amen.

Kazivači su Marici Križe pripovijedali o svojim životnim sadržajima, navikama, običajima, duhovnoj i materijalnoj kulturi, izgovarali su joj usmenoknjiževne žanrove: pjesme, priče, zagonetke, vjerovanja. Iz svih se primjera može iščitati duboka ukorijenjenost vjerskih sadržaja u biću potkalničkoga čovjeka, hrvatskoga čovjeka, i to kao dijela svakodnevice, nečega što je dio cjelovitosti osobe i njezina života, nečega što se podrazumijeva. Iščitava se vjera u Boga, Majku Božju, svetce, svjedoči se poznavanje Božjih zakona i pouzdanje u Božje vodstvo tijekom cijeloga života.

\section{Zaključak}

Dragocjen i obiman rukopis o križevačkom selu Dubovcu zapisivačice Marice Križe iz 1899. i 1904. fragmentarna je, ali prva antropološko-fokloristička studija jednoga križevačkoga lokaliteta te je vrijedan doprinos ne samo usmenoknjiževnomu i folklorističkomu gradivu križevačkoga kraja, nego i dokaz da je prikupljanje gradiva po Osnovi Antuna Radića imalo odjeka i u križevačkom kraju. Uključenost vjerskih sadržaja u svim folklorističkim opisima i u svim usmenoknjiževnim žanrovima svjedoči o ukorijenjenosti vjere u čovjeku križevačkoga kraja od davnina, iako su zapisi nastali krajem 19. stoljeća. Rukopis Marice Križe samo je djelomično obuhvatio sve ono što je Radić želio da se popiše, ali se kroz njezine zapise može bogato doznati o životu, tradicijskoj kulturi, vjerskim sadržajima i usmenoj književnosti križevačkoga sela Dubovca na prijelazu iz 19. u 20. stoljeće.

\section{Literatura}

Baran, Tanja (2012). Usmenoknjiževno nasljeđe križevačkoga kraja u kontekstu hrvatske književnosti 19. stoljeća. Doktorski rad, Filozofski fakultet Sveučilišta u Zagrebu.

Batina, Klementina (2015). Aspekti ženskoga autorstva: Komparativna analiza etnološke i foklorističke građe HAZU. Doktorski rad, Filozofski fakultet Sveučilišta u Zagrebu.

Križe, Marica (1903). Manji prinosi: Ženidba: Običaji u Dubovcu kraj Križevaca. Zbornik za narodni život i običaje, 8(1), 124-129.

Radić, Antun (1897). Osnova za sabiranje i proučavanje građe o narodnom životu. Zagreb: Tisak dioničke tiskare. 
Ravlić, Slaven (ur.) (2007). Hrvatska enciklopedija: 9: Pri-Sk. Zagreb: Leksikografski zavod Miroslav Krleža.

Vrabec, Marica (2011). Iz kulture i povijesti kraja dubovečkoga. Dubovec: vlastita naklada.

Arhivsko gradivo

HR-HAZU. Odsjek za etnologiju. Sign. K.SZ.85. Dubovec kraj Križevaca (po Osnovi).

HR-HAZU. Odsjek za etnologiju. Sign. K.SZ.109. Evidencija rukopisne građe za Zbornik za narodni život i običaje.

HR-HAZU. Odsjek za etnologiju. Sign. K.SZ.125. Ostavština Dragutina Boranića.

HR-HAZU. Odsjek za etnologiju. Sign. K.SZ.390/1,2,3,4 i 5. Pisma Marice Križe uredništvu časopisa Zbornik za narodni život i običaje od 8. veljače 1899. do 1. ožujka 1913. godine.

HR-IEF. Dokumentacija Instituta za etnologiju i folkloristiku. Križe, Marica. Folklorna građa iz Dubovca, 1904. Rkp. 446. [Institut za etnologiju i folkloristiku, Zagreb.]

Osnovna škola Ljudevita Modeca Križevci. Spomenica opće pučke škole u Dubovcu od 1872. do 1966.

Župa Dubovec. Matica krštenih, vjenčanih i umrlih od 1800. do 1991. godine.

The Anthropological-Folkloristic and Religious Aspects of Marica Križe's Oral Literary Records

Tanja Baran*

\section{Summary}

Owing to the oral literary records of Marica Križe on the village Dubovec near Križevci, we gain insight into the abundant anthropological-folkloristic and religious content which in the nineteenth century rendered the identity of the Croatian people exceptionally rich and strong. This article examines the genre-diverse content of two of Križe's manuscripts from the end of the 19th and beginning of the 20th century in order to demonstrate a practical, living faith both in the customs and in the sacramental life of the villagers of the Prigorje region at the foot of Mount Kalnik. Marica Križe is the only woman who recorded the oral literature of the Križevci area and one of approximately ten women in Croatia who recorded the life and customs of the people in accordance with „The Basics for the Collection and Study of Material on the Life of the People" by Antun Radic who took part in the Committee on the Life and Customs of the People at the Yugoslav Academy of Sciences and Arts of that time. Although she did not adopt in their entirety Radićs instructions on recording material as a norm, but moreso as a template, she did make records of the traditional and oral literary realities according to his instructions and thus recorded the living culture and religious content of a particular locality.

Key words: Marica Križe; Antun Radić; oral literary records; genres; anthropological and religious content; folkloristic material; woman recorder; Ethnology Department of the Croatian Academy of Sciences and Arts

* Tanja Baran, Ph.D., Croatian Radio-Television. Address: Prisavlje 3, 10000 Zagreb, Croatia. E-mail:tanja.baran@hrt.hr 